\title{
Regulation of adrenal and ovarian steroidogenesis by miR-132
}

\author{
Zhigang Hü,2,*, Wen-Jun Shen ${ }^{1,2}$, Fredric B Kraemer ${ }^{1,2}$ and Salman Azhar ${ }^{1,2}$ \\ ${ }^{1}$ Geriatric Research, Education and Clinical Center, Veterans Affairs Palo Alto Health Care System, Palo Alto, \\ California, USA \\ 2Division of Endocrinology, Gerontology and Metabolism, Stanford University, Stanford, California, USA \\ *(Z Hu is now at Jiangsu Key Laboratory for Molecular and Medical Biotechnology and College of Life Science, \\ Nanjing Normal University, Nanjing, China)
}

Correspondence

should be addressed

S Azhar

Email

salman.azhar@va.gov

\begin{abstract}
miR-132 is hormonally regulated in steroidogenic cells of the adrenal gland, ovary and testis. Here, we examined the potential role of miR-132 in the control of steroidogenesis.

Key Words

- steroidogenesis

Transfection of $Y 1$ adrenal cells with miR-132 increased mRNAs of 3 $\beta$-HSD and $20 \alpha-H S D$ enzymes, which catalyze the sequential conversion of pregnenolone to progesterone to biologically inactive $20 \alpha$-hydroxyprogesterone (20 $\alpha$-OHP). Overexpression of miR-132 reduced MeCP2 and StAR protein expression, basal progestin (progesterone and 20 $\alpha-\mathrm{OHP}$ )

- Star

- microRna

- miR-132

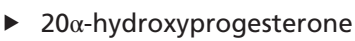
production, but enhanced their production in response to cAMP stimulation. Use of $\left[{ }^{3} \mathrm{H}\right]$ pregnenolone and free-diffusible 22(R)-hydroxycholesterol further confirmed that miR-132 promotes the production of $20 \alpha-\mathrm{OHP}$ by upregulating $3 \beta-\mathrm{HSD}$ and $20 \alpha-\mathrm{HSD}$. Evidence is also presented that StAR is a direct target of miR-132. Transient transfection of $\mathrm{Y} 1$ cells with miR-132 demonstrated that miR-132 induction of 3 $\beta-\mathrm{HSD}$ and $20 \alpha-\mathrm{HSD}$ was accompanied by significant suppression of one of its target gene products, MeCP2. In contrast, co-expression of miR-132 plus MeCP2 protein partially blocked the ability of miR-132 to upregulate the expression and function of 3 $\beta$-HSD and $20 \alpha-H S D$. Moreover, suppression of MeCP2 protein with siRNA resulted in increased expression of 3 $\beta$-HSD and $20 \alpha-H S D$, further demonstrating that miR-132 induces the expression of these two enzymes via inhibition of MeCP2. Likewise, overexpression of miR-132 increased $20 \alpha$-OHP production with and without HDL loading, while knockdown of miR-132 resulted in a significant decrease of $20 \alpha$-OHP production by granulosa cells. In conclusion, our data suggest that miR-132 attenuates steroidogenesis by repressing StAR expression and inducing $20 \alpha-\mathrm{HSD}$ via inhibition of MeCP2 to generate a biologically inactive $20 \alpha-\mathrm{OHP}$.

\section{Introduction}

Steroid hormones mediate a wide variety of vital physiological functions, including regulation of carbohydrate metabolism, inflammation and stress responses (glucocorticoids), maintenance of blood pressure and water and salt balance (mineralocorticoids) and events connected with fertility and reproduction (gonadal steroids) (Graham \& Clarke 1997, Hiort et al. 1998, Newton 2000, Katzenellenbogen et al. 2002, Pearce et al. 2003). They are mainly synthesized in the adrenal cortex, ovary, testis and placenta. The synthesis of these steroid hormones (steroidogenesis) involves multiple pathways, as well as sequential actions of steroidogenic 
enzymes associated with the endoplasmic reticulum (ER) and mitochondria (Jefcoate et al. 1992, Stocco \& Clark 1996, Stocco 2000, Kraemer \& Shen 2002, Payne \& Hales 2004, Miller 2008, LaVoie \& King 2009, Hu et al. 2010, Miller \& Bose 2011, Papadopoulos \& Miller 2012). Adrenal, ovarian and testicular steroidogenesis is primarily controlled by cell/tissue-specific trophic hormones (ACTH, LH and FSH) (Stocco \& Clark 1996, LaVoie \& King 2009, Hu et al. 2010, Miller \& Bose 2011) and is subject to both acute (Jefcoate et al. 1992, Stocco \& Clark 1996, Stocco 2000, Miller 2008, LaVoie \& King 2009, Hu et al. 2010, Miller \& Bose 2011, Papadopoulos $\&$ Miller 2012) and chronic regulation (Simpson et al. 1992, Payne \& Youngblood 1995, Payne \& Hales 2004, Sewer et al. 2007, Miller 2008, LaVoie \& King 2009, Miller $\&$ Bose 2011).

Acute steroid synthesis that occurs over minutes in response to trophic hormone stimulation is controlled at the level of delivery of substrate cholesterol from the outer mitochondrial membrane (OMM) to the inner mitochondrial membrane (IMM), where cytochrome P450 cholesterol side-chain cleavage (P450scc) enzyme (encoded by the CYP11A1 gene) resides (Jefcoate et al. 1992, Stocco \& Clark 1996, Stocco 2000, Hu et al. 2010, Miller \& Bose 2011). This step is primarily mediated by the steroidogenic acute regulatory protein (StAR). Trophic hormones rapidly induce the expression of StAR in their respective target steroidogenic cells (with the exception of steroidogenic cells of the placenta), which then facilitates the transfer of cholesterol from OMM to IMM and thereby initiates steroidogenesis (Stocco \& Clark 1996, Stocco 2000, Christenson \& Strauss III 2000, Miller \& Bose 2011). Chronic stimulation (hours to days) occurs through the trophic hormone induction of $\mathrm{P} 450$ enzymes such as CYP11A, CYP11B, CYP17, CYP19 and CYP21 and 3BHSDs, resulting in increased steroidogenic capacity of the cells (Simpson et al. 1992, Payne \& Youngblood 1995, Payne \& Hales 2004, Sewer et al. 2007, Miller 2008, LaVoie \& King 2009, Miller \& Bose 2011).

Although current evidence suggests that both acute and chronic phases of steroidogenesis are mainly regulated at the gene transcription level (Simpson et al. 1992, Payne \& Youngblood 1995, Payne \& Hales 2004, Sewer et al. 2007, Miller 2008, LaVoie \& King 2009, Manna et al. 2009, Miller \& Bose 2011), emerging evidence also suggests that steroidogenesis may be subject to posttranscriptional and posttranslational regulations (Strålfors et al. 1984, Epstein \& Orme-Johnson 1991, Arakane et al. 1997, Greenberg et al. 2001, Nair et al. 2002, Lehoux et al. 2004, Manna et al. 2009, Wang et al. 2009, Hu et al. 2012, 2013a,
2015, Kitahara et al. 2013, Menon et al. 2013, Morohaku et al. 2014). An earlier publication from our laboratory showed that scavenger receptor class B, type 1 (SR-B1), an HDL receptor that mediates bulk delivery of HDLderived CEs into the steroidogenic cells of the adrenal gland and ovary and to testicular Leydig cells under certain conditions (Azhar et al. 1998, 2002, Reaven et al. 2002, Hu et al. 2010), is also subject to posttranslational regulation by $\mathrm{Na}^{+} / \mathrm{H}^{+}$exchanger regulatory factors $1 / 2$ (NHERF1/2) (Hu et al. 2013a). In addition, we recently provided evidence that miRNAs, such as miR-125a and miRA-455, target SR-B1 mRNA, thus posttranscriptionally and negatively regulate SR-B1-mediated selective delivery of HDL cholesterol in steroidogenic cells and consequently inhibit SR-B1-mediated and HDL-supported steroidogenesis (Hu et al. 2012). In contrast, we very recently provided evidence that SIK1 protein kinase positively regulates HDL-CE transport function of SR-B1 and secondarily steroidogenesis (Hu et al. 2015).

MicroRNAs (miRs) comprise a novel class of noncoding RNA single-stranded small RNA transcripts of 20-25 nucleotides that regulate gene expression at the posttranscriptional level. They have emerged as key posttranscriptional regulators of gene expression in metazoan animals, plants, protozoa and viruses (Ambros 2004, Jones-Rhoades et al. 2006, Bushati \& Cohen 2007, Bartel 2009, Fabian et al. 2010, Skalsky \& Cullen 2010). Recently, we reported the high-throughput expression profiling of miRNAs in rat adrenals in response to in vivo treatment of animals with hormones, ACTH, 17 $\alpha$-ethinyl estradiol (17 $\alpha$-E2) or dexamethasone (Hu et al. 2013b). Among the various adrenal miRNAs whose expression was altered in response to treatment of rats with any of these three hormones, the most robust effect was on the expression of miR-132 and miR-212 (3-4 folds' induction) in response to ACTH treatment (Hu et al. 2013b). We further demonstrated that the expression of both miR-132 and miR-212 was upregulated in primary rat ovarian granulosa cells and mouse testicular Leydig tumor cells by the second messenger of the tropic hormone, cAMP (Hu et al. 2013b). These findings, coupled with other reports (Fiedler et al. 2008, Yao et al. 2010), suggest the possibility that these two miRNAs may participate in the trophic hormone regulation of steroidogenesis. miR-132, together with miR-212, comprises the evolutionary conserved miR-132/212 family, encoded from the same intron of a small non-coding gene that is located on chromosome 11 in mice, chromosome 10 in rats and chromosome 17 in humans. Mature miRNA-132/-212 share the same seed sequence (Wanet et al. 2012, Remenyi et al. 2013).

Published by Bioscientifica Ltd. 
Here, we examined the potential role of miR-132 in the regulation of steroidogenesis in a model adrenal cell line, Y1 cells. Given that miR-212 expression was several hundredfold lower, as compared to miR-132, in all of the steroidogenic cells examined here, we focused our studies primarily on miR-132. Our findings suggest that miR-132 inhibits steroidogenesis by causing the direct repression of StAR protein expression and by promoting the increased conversion of biologically active progesterone into biologically inactive 20 $\alpha$-hydroxyprogesterone (20 $\alpha-\mathrm{OHP})$. The latter effect of miR-132 is mediated by increased expression of $20 \alpha$-hydroxysteroid dehydrogenase (20 $\alpha$-HSD) via the miR-132 inhibition of methyl-DNA-binding protein, MeCP2; $20 \alpha$-HSD catalyzes the conversion of progesterone into its inactive form, 20 $\alpha$-OHP (Mao et al. 1997).

\section{Materials and methods}

\section{Materials}

22(R)-hydroxycholesterol, 17 $\quad$-estradiol, N6,2'-Odibutyryladenosine $3^{\prime}, 5^{\prime}$-cyclic monophosphate ( $\left.\mathrm{Bt}_{2} \mathrm{CAMP}\right)$, progesterone, 20 $\alpha$-OHP, 22(R)-hydroxycholesterol and fatty acid-free bovine serum albumin were supplied by Sigma-Aldrich. 20 2 -hydroxyprogesterone $\quad\left[1,2-{ }^{3} \mathrm{H}(\mathrm{N})\right]$ (40-60 Ci/mmol;1.48-2.22 TBq/mmol)andprogesterone[1,2$\left.{ }^{3} \mathrm{H}\right](40-60 \mathrm{Ci} / \mathrm{mmol} ; 1.48-2.22 \mathrm{TBq} / \mathrm{mmol})$ were purchased from American Radiolabeled Chemicals. Pregnenolone, [7-3 $\mathrm{H}(\mathrm{N})] \quad(10-25 \mathrm{Ci} / \mathrm{mmol} ; \quad 370-925 \mathrm{GBq} / \mathrm{mmol})$ was supplied by PerkinElmer. StAR (D10H12) XP rabbit mAb, GAPDH (14C10) rabbit mAb and MeCP2 (D4F3) XP rabbit $\mathrm{mAb}$ were obtained from Cell Signaling Technology. Purified anti-SF-1 polyclonal antibody (07-618) was purchased from EMD Millipore. All other chemicals used were of analytical grade.

\section{Animals and hormonal treatment}

All animal experiments were performed according to the procedures approved by the VA Palo Alto Health Care System Animal Care and Use Committee (IACUC). Groups of eight 225- to 250-g male Sprague-Dawley rats were purchased from Harlan Laboratories (Indianapolis, IN, USA). They were allowed to acclimatize to a new controlled environment $\left(25 \pm 2^{\circ} \mathrm{C}, 55 \% \pm 55\right.$ relative humidity with a 12-h light-darkness cycle) for approximately 1 week. Subsequently, the rats were randomly assigned to one of two groups (4 rats in each group): group 1 rats were treated subcutaneously with phosphate-buffered saline
(PBS) every $24 \mathrm{~h}$ for 4 days, with the last injection on day 4 given $1 \mathrm{~h}$ prior to harvesting of adrenal tissues, and the rats in group two were treated subcutaneously with ACTH (Cortrosyn) (10IU) every $24 \mathrm{~h}$ for 4 days, and again, the ACTH injections on day 4 given $1 \mathrm{~h}$ prior to killing the animals. The collected adrenals were stored frozen in liquid nitrogen until their use in RNA isolation. Similarly, immature female Sprague-Dawley rats (21-23 days old, Harlan Laboratories) were injected subcutaneously with $17 \beta$-estradiol ( $1 \mathrm{mg} / \mathrm{kg} \mathrm{BW})$ daily for 5 days. The animals were killed $24 \mathrm{~h}$ after their last injection, and the granulosa cells were isolated from the ovaries using the follicle puncture method as described previously (Azhar et al. 1998).

\section{Isolation, culture and CAMP treatment of rat ovarian granulosa cells}

Isolated granulosa cells (Azhar et al. 1998) were cultured in $35-\mathrm{mm}$ culture dishes that were precoated with $1 \%$ fetal bovine serum overnight. Dishes were plated with $1-2 \times 10^{5}$ cells in Dulbecco's modified Eagle's (DME)-F12 culture medium containing $15 \mathrm{mM}$ Hepes, $1 \mathrm{mg} / \mathrm{mL}$ bovine serum albumin, $2 \mu \mathrm{g} / \mathrm{mL}$ insulin, $5 \mu \mathrm{g} / \mathrm{mL}$ transferrin, $100 \mathrm{ng} / \mathrm{mL}$ hydrocortisone, $100 \mu \mathrm{g} / \mathrm{mL}$ streptomycin and $100 \mathrm{U} / \mathrm{mL}$ penicillin G. After $72 \mathrm{~h}$ of culture, cells were treated with or without $\mathrm{Bt}_{2} \mathrm{CAMP}(2.5 \mathrm{mM})$ for $24 \mathrm{~h}$ and subsequently used for experimentation.

\section{Cell culture}

Y1 mouse adrenocortical cells (ATCCCCL-79), MLTC-1 mouse Leydig tumor cells (ATCCCRL-2065) and CHO-K1 cells (ATCCCCL-61) were purchased from the American Type Culture Collection (ATCC). Y1 cells were cultured in Ham's F-12K (Kaigh's) medium containing $2.5 \%$ fetal bovine serum, $15 \%$ horse serum and 100 units $/ \mathrm{mL}$ penicillin and $100 \mu \mathrm{g} / \mathrm{mL}$ streptomycin. In contrast to mouse adrenocortical cells/adrenal gland that produce corticosterone as the major steroid product, cultured Y1 cells, both under basal conditions and in response to trophic hormone stimulation, synthesize and secrete $20 \alpha$-hydroxy- $\Delta^{4}$-pregnene-3-one

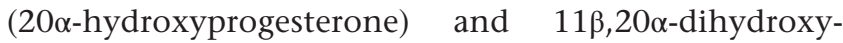
$\Delta^{4}$-pregnene-3-one (11 $\beta, 20 \alpha$-hydroxyprogesterone) (Rainey et al. 2004). Y1 cells also secrete small quantities of progesterone. The lack of production of a normal steroid, corticosterone, by these cells is mainly attributed to CYP21 (steroid 21-hydroxylase) deficiency (Parker et al. 1985). MLTC-1 cells were cultured in

Published by Bioscientifica Ltd. 
RPMI-1640 medium supplemented with $10 \%$ fetal bovine serum plus $100 \mathrm{U} / \mathrm{mL}$ penicillin and $100 \mu \mathrm{g} / \mathrm{mL}$ streptomycin. These cells mainly secrete progesterone and a small amount of testosterone (Manna et al. 2006). CHO-K1 cells were cultured in F-12K medium containing $10 \%$ fetal bovine serum and 100 units $/ \mathrm{ml}$ penicillin and $100 \mu \mathrm{g} / \mathrm{mL}$ streptomycin. All cell cultures were maintained at $37^{\circ} \mathrm{C}$ in a tissue culture incubator containing 5\% $\mathrm{CO}_{2}, 95 \%$ air. Most of the tissue culture supplies were purchased from Invitrogen through Invitrogen Cell Culture Media.

\section{Plasmid constructs}

The open reading frame of mouse steroidogenic acute regulatory protein (mStAR) was amplified and subcloned into pcDNA6-HisA-V5 vector, and the constructed plasmid was designated as pcDNA6-mStAR-V5. The mouse StAR (166bp (562-727 nucleotides (nt) from the start of the 3'UTR) and 213 bp (1185-1397 nt from the start of the 3'-UTR)) containing miR-132-binding site I and the miR-132-binding site II, were amplified by PCR and ligated into pGEM-T vector (Promega), and, subsequently, recombinant T-plasmids were digested with Hind III and Spe I and cloned into the $3^{\prime}$ end of the pMIRREPORT Luciferase vector with CMV promoter (Applied Biosystems) at Hind III and Spe I sites. These two plasmids were designed as pMIR-StAR-3UTR-132-I and pMIR-StAR3UTR-132-II. Mutagenesis of the miR-132-binding sites was carried out according to the instructions supplied with the Quick-change II site-directed mutagenesis kit (Stratagene) employing recombinant T-plasmids containing mStAR 3'-UTR fragments. The mutated mStAR $3^{\prime}$-UTR fragments were digested with Spe I and Hind III

Table 1 Primers used for PCR gene cloning, site-directed mutagenesis and quantitative real-time PCR.

Plasmid/gene
pcDNA6-mStar-V5
pMIR-Star-3UTR-132-I
pMIR-Star-3UTR-132-II
pMIR-Star-3UTR-132-IM
pMIR-Star-3UTR-132-IIM

Mouse DAX-1 (NrOb1)

Mouse SF-1 (Nr5a1)

Mouse AArhgap32 (Arhgap32)

Mouse MeCP2 (Mecp2)

Mouse CtBP1(Ctbp1)

Mouse HDAC3 (Hdac3)

Mouse StAR (Star)

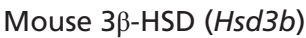

Mouse CYP11A1 (Cyp11a1; P450scc)

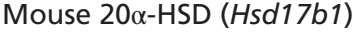

Mouse 36B4 (Rp/p0)

\begin{tabular}{l} 
Forward (F) and reverse (R) primers \\
\hline 5'-CTGAAAGCTTATGTTCCTCGCTACGTTCAAG-3'-F \\
5'-CTGATCTAGAACACTGGGCCTCAGAGGCAG-3'-R \\
5'-CTGAACTAGTGGAATCACAGCTTCAGCAG-3'-F \\
5'-CTGAAAGCTTTGCCTCTGCCACTTGAGTG-3'-R \\
5'-CTGAACTAGTACAGCATCCTGGCAGGAAG-3'-F \\
5'-CTGAAAGCTTAGCTCTACTGACTTCTAGC-3'-R \\
5'-TGTCATTTGACACATTAGATTCTTTCCTAAAAAGG-3'-F \\
5'-GCCTCTAAATACAGTAAACTGTGTAATCTAAGAAA-3'-R \\
5'-GATAAAGTGACCGTTCTATTGTTTATAG-3'-F \\
5'- CTATTTCACTGGCAAGATAACAAATATC-3'-R \\
5'-AAGGGACCGTGCTCTTTAAC-3'-F \\
5'-GGATGTGCTCAGTAAGGATCTG-3'-R \\
5'-GTCTCAAGTTCCTCATCCTCTTC-3'-F \\
5'-GGGTAGTGACACAAGGTGTAAT-3'-R \\
5'-TTGAAGTGCCCCAGGTTCTT-3'-F \\
5'-TATATCCCATCCACAATGCCATAC-3'-R \\
5'-ATGAGCCACTACAACCTTCAG-3'-F \\
5'-AGCTTTCGTGTCCAACCTTC-3'-R \\
5'-GGCAGCGGGTTTGACAATA-3'-F \\
5'-GCACACTGCGATGCCTAGATC-3'-R \\
5'-TCCCCTCATTTGTTCCTTCTG-3'-F \\
5'-TCCTTGCCACTGTACTTCATC-3'-R \\
5'-CGGAGCAGAGTGGTGTCATC-3'-F \\
5'-TGAGTTTAGTTTAGTCTTGGAGGGACTTC-3'-R \\
5'-AGCGAGATCTGGGCTATGA-3'-F \\
5'-CCCTGTGCTGTTCCACTATT-3'-R \\
5'-CGCATCAAGCAGCAAAATTC-3'-F \\
5'-ATGCGCTCCCCAAATATAAC-3'-R \\
5'-GCCTAAAGATGAGCATGGAAAC-3'-F \\
5'-TTAAAGTTAGACACCCCGATGG-3'-R \\
5'-GAAAAGGTCAAGGCCTTCCT-3'-F \\
5'-CGAAGAGACCGAATCCCATA-3'-R
\end{tabular}

Restriction enzyme sites

HindIII/Xbal

HindIII/Spe I

HindIII/Spe I

Mutagenesis

Mutagenesis

qRT-PCR primers

qRT-PCR primers

qRT-PCR primers

qRT-PCR primers

qRT-PCR primers

qRT-PCR primers

qRT-PCR primers

qRT-PCR primers

qRT-PCR primers

qRT-PCR primers

qRT-PCR primers

Restriction enzyme sites are underlined. Gene symbols are listed in italics.

Arhgap32, rho GTPase activating protein 32; Ctbp1, C-terminal binding protein 1; Hdac3, histone deacetylase 3; Hsd17b1, hydroxysteroid 17-beta dehydrogenase 1; Hsd3b, hydroxy-delta-5-steroid dehydrogenase, 3beta-and steroid delta isomerase; Mecp2, methyl-CpG binding protein 2; NrOb1, nuclear receptor subfamily 0 Group B member 1; Nr5a1, nuclear receptor subfamily 5 group A member 1; Rplp0, acidic ribosomal phosphoprotein P0; Star, steroidogenic acute regulatory protein.

http://jme.endocrinology-journals.org DOI: 10.1530/JME-17-0011
() 2017 Society for Endocrinology Printed in Great Britain
Published by Bioscientifica Ltd 
and cloned into the 3 ' end of the pMIR-REPORT Luciferase vector. The mutated fragment plasmids were named as pMIR-StAR-3UTR-132-IM and pMIR-StAR-3UTR-132-IIM. The sequence of the inserted fragments was confirmed by sequencing. Primers for plasmid construction and mutagenesis are listed in Table 1.

\section{qRT-PCR analyses of miR-132 and miR-212}

Total RNAs were extracted from adrenal tissues, cultured rat ovarian granulosa cells, MLTC-1 Leydig cells or Y-1 adrenal cells using miRNeasy Isolation Mini Kit (Qiagen) following the manufacturer's protocol. RNA samples were reverse transcribed using the mercury LNA universal RT microRNA PCR kit (Exiqon Inc., Woburn, MA, USA). Following cDNA synthesis, quantitative real-time PCR was performed on an ABI Prism 7900 HT system using SYBR Green Real-time Master Mix (Invitrogen) and microRNA LNA PCR primer sets for miR-132 and miR-212 (Exiqon Inc.). Fold-changes of mRNA levels were determined after normalization to internal control, U6mRNA levels, a small nuclear gene, using the $2^{-\Delta \Delta \mathrm{Ct}}$ method (Hu et al. 2013b).

\section{Quantitative RT-PCR (qRT-PCR)}

Total RNA from Y-1 cells transfected with \pm miR-132 mimic or scrambled oligonucleotide and treated with $\pm \mathrm{Bt}_{2} \mathrm{cAMP}$ was extracted using a miRNeasy Mini Kit (Qiagen). To measure mRNA expression, total RNA $(2 \mu \mathrm{g})$ from Y-1 cell samples was reverse transcribed using Superscript Reverse Transcriptase (Invitrogen) and oligo (dT) primers. The resulting complementary cDNA samples were used for qRT-PCR using SYBR Green Real-time Master Mix (Invitrogen) and specific primers as listed in Table 1. qPCR was performed on an ABI Prism 7900 HT quantitative PCR system (Applied Biosystems). Target mRNA expression in each sample was normalized to the $36 \mathrm{~B} 4$ signal. The $2-\Delta \Delta \mathrm{Ct}$ method was used to calculate relative mRNA expression levels.

\section{Luciferase reporter assays}

For the luciferase assay, $\mathrm{CHO}$ cells at a density of $1 \times 10^{5}$ per well in 24-well plates were co-transfected with pMIRREPORT reporter constructs containing the 3' UTR of the StAR gene containing native or mutant site I- or site II-binding site for miR-132 \pm miR-132 mimic or scrambled oligonucleotide using Lipofectamine 2000 transfection reagent (Invitrogen). Twenty-four hours after transfection, cells were harvested and lysed with passive lysis buffer (Promega) according to the manufacturer's instructions. Reporter activity was measured on a SpectraMaxL luminescence microplate reader (Molecular Devices). The pRL-TK vector (Promega) Renilla luciferase control reporter vector, which provides constitutive expression of Renilla luciferase, was used as an internal control. The results are expressed as relative luciferase activities (firefly luciferase/Renilla luciferase).

\section{Cell transfection}

miR-132 mimic was purchased from Ambion. For transient transfections, Y-1 cells were plated $12 \mathrm{~h}$ before transfection at 50\% confluence and then transfected with miR-132 mimic or scrambled oligonucleotide using Lipofectamine 2000 transfection reagent. For co-transfection experiments with miRNA and plasmid, pcDNA6-LacZ was used as control plasmid. Thirty-six to forty-eight hours after transfection, the cells were treated with $\pm \mathrm{Bt}_{2} \mathrm{cAMP}$ $(2.5 \mathrm{mM})$ for $6 \mathrm{~h}$ and subsequently, the expression of DAX-

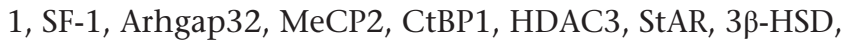
CYP11A1 and 20 $\alpha$-HSD was assessed by qRT-PCR and/or Western blotting.

\section{Western blot analyses}

Y1 cells were harvested and homogenized in RIPA buffer (25 mM Tris-HCl, pH 7.6, $150 \mathrm{mM} \mathrm{NaCl}, 1 \%$ NP-40, 1\% sodium deoxycholate and $0.1 \%$ SDS) supplemented with Thermo Scientific HaltProtease Inhibitor Cocktail (1 mM AEBSF, $800 \mathrm{nM}$ aprotinin, $50 \mathrm{nM}$ bestatin, $15 \mathrm{nM}$ E-64, $5 \mathrm{mM}$ EDTA, $20 \mathrm{nM}$ leupeptin, $10 \mathrm{nM}$ pepstatin). The lysates were incubated for $20 \mathrm{~min}$ on ice and subsequently centrifuged at $10,000 \boldsymbol{g}$ for $5 \mathrm{~min}$. Supernatants were collected, and protein concentrations were determined using the Pierce BCA Protein Assay Kit. Suitable aliquots of samples were mixed with equal volumes of $5 \times$ Laemmli sample buffer (120 mM Tris-HCl (pH 6.8), 2\% SDS (wt/vol), $10 \%$ sucrose ( $\mathrm{wt} / \mathrm{vol})$ and $1 \%$ 2-mercaptoethanol), and $10-20 \mu \mathrm{g}$ of total protein of each sample was subjected to $10 \%$ SDS-PAGE under denaturing conditions. Protein markers were also loaded on the gels. Following electrophoretic separation, the proteins were transferred to Immobilon-P PVDF Transfer membrane (EMD Millipore) using standard techniques. Blotted membranes were blocked with Odyssey blocking buffer (LI-COR Biosciences, Lincoln, NE, USA) for $1 \mathrm{~h}$ at room temperature and then incubated with anti-MeCP2, anti-SF-1, anti-StAR http://jme.endocrinology-journals.org DOI: 10.1530/JME-17-0011
() 2017 Society for Endocrinology Printed in Great Britain
Published by Bioscientifica Ltd 
or anti-GAPDH. After three washes with Tris-buffered saline containing $0.1 \%$ Tween 20 , the membranes were incubated with IRDye 800CW goat anti-rabbit secondary antibody (LI-COR) for $1 \mathrm{~h}$. Protein bands were detected with the Odyssey Infrared Imaging system (LI-COR Biosciences).

\section{Measurement of progesterone and $20 \alpha$-OHP secretion}

Y1 cells were transfected with \pm miR-132 mimic or scrambled oligonucleotide for $48 \mathrm{~h}$ and were subsequently treated with $\pm \mathrm{Bt}_{2} \mathrm{cAMP} \quad(2.5 \mathrm{mM})$ or $22(\mathrm{R})$-hydroxycholesterol $(10 \mu \mathrm{M})$ for $6 \mathrm{~h}$. After incubation, progesterone and $20 \alpha$-OHP in the medium was determined by radioimmunoassay (Azhar et al. 1998).

\section{Thin-layer chromatography}

Y1 cells were transfected with \pm miR-132 mimic or scrambled oligonucleotide for $48 \mathrm{~h}$ and were subsequently incubated with $\left[{ }^{3} \mathrm{H}\right]$ pregnenolone $(1 \mu \mathrm{Ci} / \mathrm{mL})+$ unlabeled pregnenolone $(10 \mu \mathrm{M})$ for $6 \mathrm{~h}$. After incubation, media and cell samples were extracted with diethyl ether, and the ether phase in each case after drying under nitrogen was subjected to thin-layer chromatography using chloroform-ether $(5: 1, \mathrm{v} / \mathrm{v})$ as described by Jones and Hsueh (Jones \& Hsueh 1982). The $\left[{ }^{3} \mathrm{H}\right]$ progesterone and $\left[{ }^{3} \mathrm{H}\right] 20 \alpha-\mathrm{OHP}$ spots were scraped from the plate and counted for the determination of radioactivity.

\section{Statistical analysis}

The results are presented as the means \pm S.E. for at least three independent experiments. All data were tested for normality (Kolmogorov-Smirnov test) and homogeneity of variances (Bartlett's test). We used one-way ANOVA or two-way ANOVA to analyze the corresponding data when the assumptions for parametric analyses were met. Statistical analyses were performed using ANOVA followed by the Bonferroni's post-test using GraphPad Prism Software, Prism 6 (GraphPad Software). Descriptive statistics are presented as mean \pm standard error, and the significance level is set at $\alpha=0.05$.

\section{Results}

\section{Relative expression and hormonal regulation of miR- 132 and/miR-212}

miR-132 and miR-212 are derived from the same primary microRNA transcript and these two miRNAs share the same seed sequence (Wanet et al. 2012, Remenyi et al. 2013). We first determined the relative expression of these two microRNAs by qRT-PCR under basal conditions and in response to hormonal stimulation of rat adrenals, Y1 mouse adrenocortical cells, MLTC-1 mouse Leydig tumor cells and primary rat ovarian granulosa cells. Dishes of MLTC-1 and Y1 cells treated with or without $\mathrm{Bt}_{2} \mathrm{CAMP}$ $(2.5 \mathrm{mM})$ for $6 \mathrm{~h}$, and granulosa cells treated with or without $\mathrm{Bt}_{2} \mathrm{cAMP}(2.5 \mathrm{mM})$ for $24 \mathrm{~h}$, were subjected to RNA isolation followed by qRT-PCR. Likewise, groups of rats were treated subcutaneously with ACTH (10IU daily for 4 days) or a vehicle (control), and adrenal samples were subjected to RNA isolation and qRT-PCR. As shown in Fig. 1, miR-132 was expressed at much higher basal levels than miR-212 in MLTC-1, Y1 and granulosa cells and the adrenal gland (approximately 300-, 250-, 270and 220-fold, respectively). Treatment of MLTC-1, Y1 and
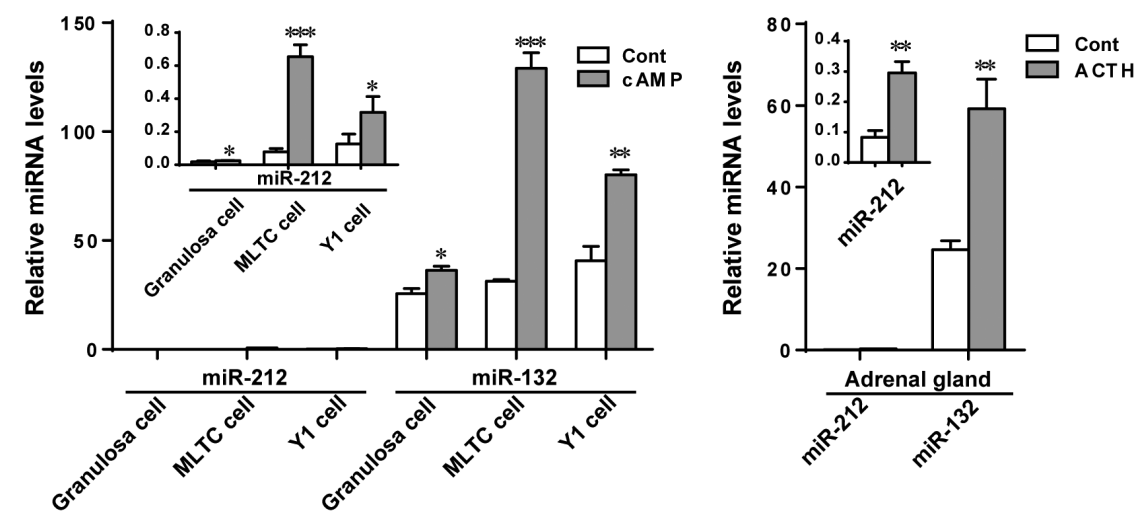

Figure 1

Basal expression and hormonal regulation of miR-132 and miR-212 in mouse MLTC-1 Leydig tumor cells, rat ovarian granulosa cells, mouse $\mathrm{Y} 1$ adrenal cells and rat adrenal glands. Cultured MLTC-1 and $\mathrm{Y} 1$ cells were treated with $\pm \mathrm{Bt}_{2} \mathrm{CAMP}$ $(2.5 \mathrm{mM})$ for $6 \mathrm{~h}$ and granulosa cells $\pm \mathrm{Bt}_{2} \mathrm{CAMP}$ ( $2.5 \mathrm{mM}$ ) for $24 \mathrm{~h}$, and isolated RNA samples analyzed for miR-132 and miR-212 expression by qRT-PCR. Likewise, groups of rats were treated subcutaneously with ACTH (10IU every $24 \mathrm{~h}$ for 4 days) or a vehicle (control), and adrenal samples were subjected to total RNA isolation. Isolated RNA samples were analyzed for expression of miR-132 and miR-212 by qRT-PCR. miR-132 and miR-212 were normalized to the housekeeping gene U6. We used one-way ANOVA to compare the differences between control and treated samples. Data are presented as means \pm s.e. $(n=4)$. ${ }^{*} P<0.05 ;{ }^{*} P<0.01 ; * * * P<0.001$.

http://jme.endocrinology-journals.org DOI: 10.1530/JME-17-0011
C) 2017 Society for Endocrinology Printed in Great Britain 
granulosa cells with $\mathrm{Bt}_{2} \mathrm{CAMP}$ or adrenals with $\mathrm{ACTH}$ in vivo upregulated the expression of both miRNAs, although the extent of stimulation varied between approximately 0.4fold to 5 -fold (Fig. 1). In view of the very low expression of miR-212, we focused further studies on miR-132.

\section{Increased miR-132 expression was associated with repression of StAR protein expression, activation of steroidogenic enzymes and modulation of steroidogenesis in $\mathrm{Y} 1$ cells}

The above results showing that miR-132 expression is increased in intact adrenals and the steroidogenic cells, granulosa, MLTC-1 and Y1 cells and is increased in response to trophic hormone or $\mathrm{Bt}_{2} \mathrm{CAMP}$ (Fig. 1) raised the possibility that miR-132 is involved in the regulation of steroidogenesis. To test this possibility, we transfected Y1 cells with miR-132 mimic or scrambled oligonucleotide, and cells were subsequently analyzed for the expression of putative miR-132 target genes (Arhgap32, MeCP2, CtBP1 and HDAC3), steroidogenic transcription factors (DAX-1 and SF-1), StAR protein $(9,10,14,19)$, steroidogenic

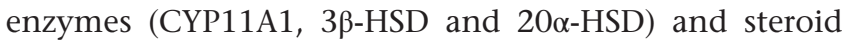

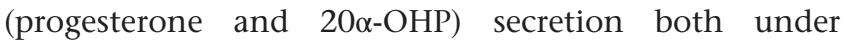
basal conditions and in response to cAMP stimulation. qRT-PCR results demonstrated that overexpression of
miR-132 under basal conditions increased mRNA levels

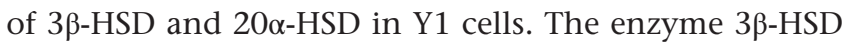
catalyzes the conversion of pregnenolone to progesterone, whereas $20 \alpha-H S D$ catalyzes the conversion of progesterone into its inactive form $20 \alpha-\mathrm{OHP}$. However, no changes in mRNA levels were noted for DAX-1, SF-1, Arhgap32, MeCP2, CtBP1, HDAC3, StAR and CYP11A1 (Fig. 2A). In contrast, Western blot analysis showed reduced protein levels of MeCP2 and StAR in cells transfected with miR132 (Fig. 2B). To investigate the effects of miR-132 on steroid production, we collected media from the cultured miR-132 and scrambled oligonucleotide-transfected cells and assessed progesterone and 20 $\alpha$-OHP concentrations (Fig. 2C). Overexpression of miR-132 significantly decreased the basal levels of both secreted progesterone and $20 \alpha-\mathrm{OHP}$.

We next assessed the effects of cAMP treatment of control (scrambled oligonucleotide) and miR-132 transfected Y1 cells on the mRNA levels of various proteins noted above and on the secreted levels of two progestins, progesterone and 20 $\alpha$-OHP. Like basal transfected cells, miR-132-transfected and $\mathrm{Bt}_{2} \mathrm{cAMP}$-treated cells also

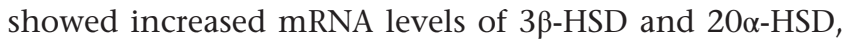
while mRNA levels of other proteins were not affected (Fig. 2A). Likewise, overexpression of miR-132 decreased MeCP2 and StAR protein levels in cAMP-stimulated cells,

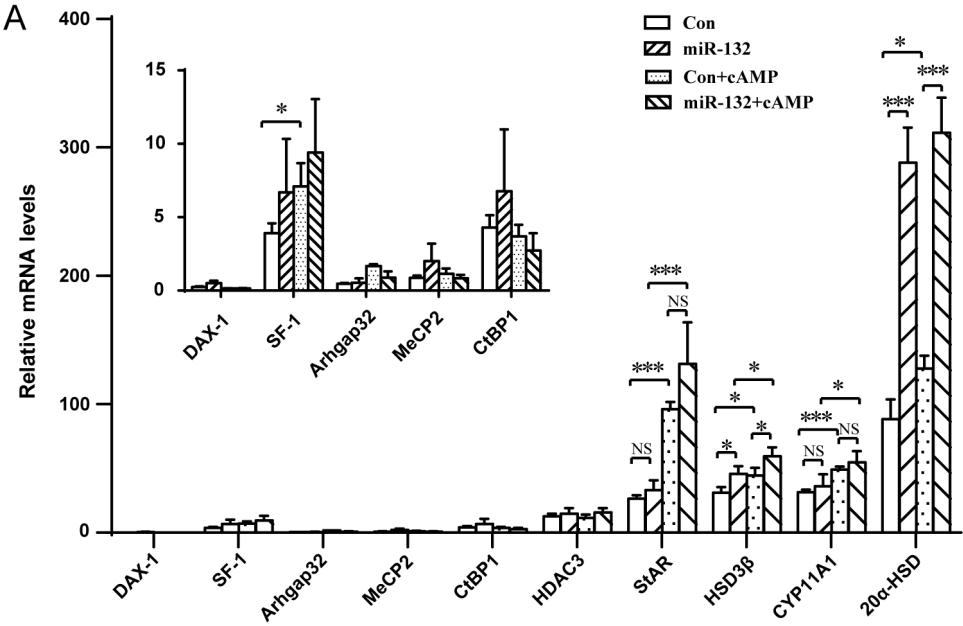

B

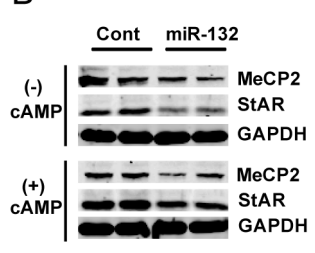

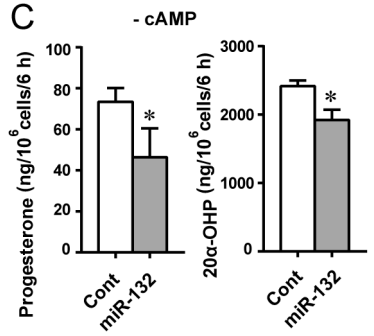

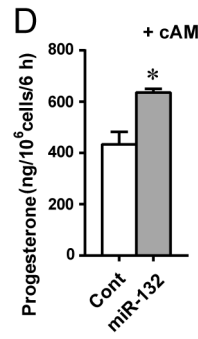

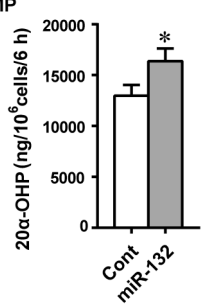

\section{Figure 2}

Effects of miR-132 overexpression on putative miR-132 sensitive genes and steroid production in $\mathrm{Y} 1$ cells. $\mathrm{Y}-1$ adrenal cells were plated $12 \mathrm{~h}$ before transfection at $50 \%$ confluence and then transfected with miR-132 mimic or scrambled oligonucleotide. Thirty-six to $48 \mathrm{~h}$ after transfection, the cells were incubated under basal or cAMP-stimulated $(2.5 \mathrm{mM})$ conditions for $6 \mathrm{~h}$ and, subsequently, the expression of DAX-1, SF-1, Arhgap32, MeCP2, CtBP1, HDAC3, StAR, 3 $\beta$-HSD, CYP11A1 and 20 $\alpha$-HSD measured by qRT-PCR (A) and/or Western blotting (B) as described under the Experimental Section. The media samples without (C) or with (D) CAMP treatment were analyzed for progesterone and

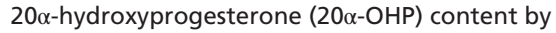
radioimmunoassay. We used two-way ANOVA to compare the differences among different samples. Data are presented as means \pm S.E. $(n=4)$. ${ }^{*} P<0.05 ;{ }^{*} P<0.01 ; * * * P<0.001$. http://jme.endocrinology-journals.org DOI: 10.1530/JME-17-0011
(C) 2017 Society for Endocrinology Printed in Great Britain 
although cAMP treatment rescued the miR-132 reduced StAR protein to the basal level (Fig. 2B). To investigate the function of miR-132-induced increases in $3 \beta-H S D$ and $20 \alpha$-HSD activity, we analyzed the secreted levels

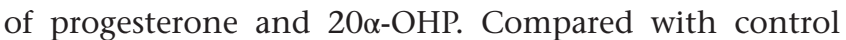
(scrambled oligonucleotide), the overexpression of miR-132 increased the levels of both progesterone and $20 \alpha-O H P$ in the culture medium in response to cAMP treatment (Fig. 2D). Furthermore, the cells secreted roughly 25 -fold more $20 \alpha$-OHP into the medium relative to progesterone. These results demonstrate that miR-132 overexpression promotes the formation of biologically inactive progestin, $20 \alpha-\mathrm{OHP}$, by enhancing the functional expression of $20 \alpha-H S D$ activity.

To further study miR-132 stimulation of $20 \alpha-\mathrm{OHP}$ production, we followed the sequential conversion of $\left[{ }^{3} \mathrm{H}\right]$ pregnenolone to $\left[{ }^{3} \mathrm{H}\right]$ progesterone and $\left[{ }^{3} \mathrm{H}\right]$ $20 \alpha-\mathrm{OHP}$ and the formation of progesterone and $20 \alpha-\mathrm{OHP}$ from 22(R)-hydroxycholesterol in Y1 cells transfected with miR-132 (or control scrambled oligonucleotide). 22(R)-hydroxycholesterol is a freely diffusible cholesterol derivative, which does not require StAR protein for its transport to mitochondria for catabolism by the P450scc (CYP11A) enzyme for the formation of the common steroid precursor pregnenolone. Results presented in Fig. 3 demonstrate that transfection of $\mathrm{Y} 1$ cells with
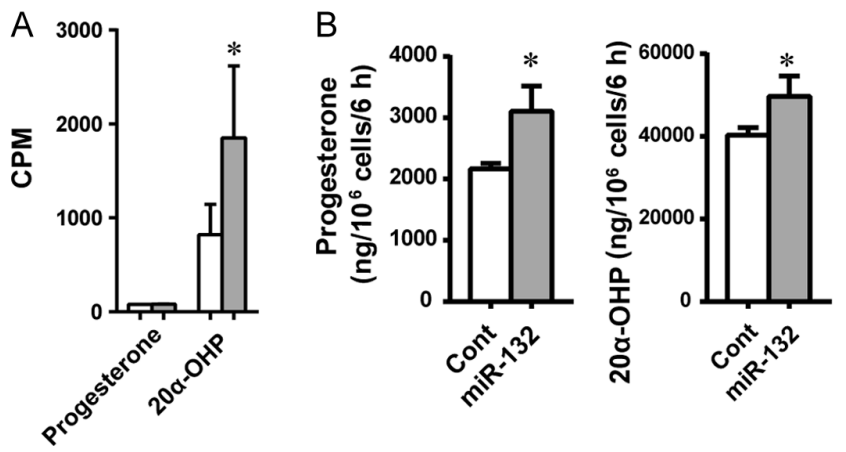

Figure 3

Effects of miR-132 on cellular conversion of [ $\left.{ }^{3} \mathrm{H}\right]$ labeled pregnenolone and 22(R)-hydroxycholesterol to progestins in Y1 cells. Y-1 adrenal cells were plated $12 \mathrm{~h}$ before transfection at $50 \%$ confluence and then transfected with miR-132 mimic or scrambled oligonucleotide. Thirty-six to $48 \mathrm{~h}$ after transfection, the cells were incubated with $\left[{ }^{3} \mathrm{H}\right]$ pregnenolone $(1 \mu \mathrm{Ci} / \mathrm{mL} ; 10 \mu \mathrm{M})$ or $22(\mathrm{R})$-hydroxycholesterol $(10 \mu \mathrm{M})$ for $6 \mathrm{~h}$, the precursor and free diffusable cholesterol substrate, respectively. $(\mathrm{A}),\left[{ }^{3} \mathrm{H}\right]$ pregnenolone-treated media samples were quantified for the accumulated levels of $\left[{ }^{3} \mathrm{H}\right]$ progesterone/[3 $\left.\mathrm{H}\right] 20 \alpha-\mathrm{OHP}$ by thin-layer chromatography (TLC). (B) 22(R)-hydroxycholesterol treated samples were analyzed for progesterone and $20 \alpha$-OHP by radioimmunoassay (RIA) techniques, respectively. For these studies, transfected cells were not further stimulated with CAMP. One-way ANOVA was used to assess the differences between control and miR-132 transfected samples. Data are presented as means \pm S.E. $(n=4) .{ }^{\star} P<0.05$.
miR-132 increased the conversion of $\left[{ }^{3} \mathrm{H}\right]$ pregnenolone into $\left[{ }^{3} \mathrm{H}\right] 20 \alpha-\mathrm{OHP}$ (Fig. 3A) and preferentially enhanced the production of 20 $\alpha$-OHP from 22(R)-hydroxycholesterol (Fig. 3B). These data further confirm the finding that miR-132 promotes the production of $20 \alpha$-OHP by upregulating the functional expression of $20 \alpha-H S D$.

\section{miR-132 suppresses StAR protein expression by targeting specific sites within the 3' UTR of StAR}

The results presented in Fig. 2A and 2B raised the possibility that miR-132 suppression of basal steroidogenesis might be linked to the observed inhibition of StAR protein expression (Fig. 2B). Here, we directly assessed the binding of the miR-132 to the 3'-UTR of StAR and regulation of its expression level by carrying out a luciferase reporter assay. Individual fragments of the 3' UTR region of the StAR gene containing site I, mutated site I, site II or mutated site II were inserted downstream of the luciferase open reading frame of pMIR-REPORT vector (Fig. 4A). CHO cells were co-transfected individually with StAR-3'-UTR (site I, site II or respective mutated sites) \pm miR-132 for $36 \mathrm{~h}$ followed by determination of luciferase activities. Overexpression of

\section{A mmu-miR-132-3P}

Mice StAR 3'UTR Site I (WT) StAR 3'UTR Site I (MUT)

mmu-miR-132-3p Site I

Mice StAR 3'UTR Site II (WT) StAR 3'UTR Site II (MUT)

mmu-miR-132-3p Site II
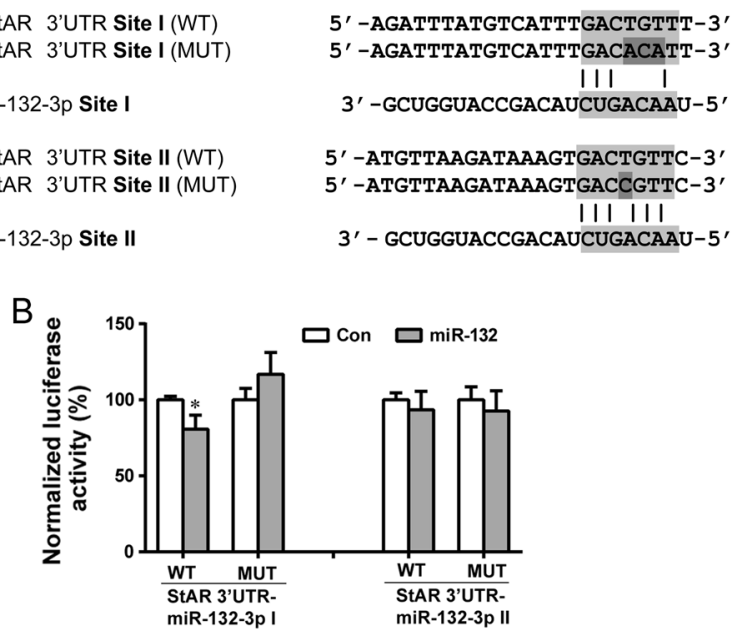

Figure 4

miR-132-binding site I in the 3' UTR of the mouse StAR gene mediates the downregulation of StAR expression by miR-132. (A) Seed sequences of the putative miR-132-binding sites (site I and site II) in the $3^{\prime}$ UTR of mouse StAR. For the reporter gene assay, the $3^{\prime}$ UTR region of the StAR gene-containing site I, mutated site I, site II or mutated site II for miR-132 was inserted downstream of the luciferase open reading frame of PMIR-REPORT vector. (B) CHO cells were co-transfected with the STAR 3' UTR (containing putative site I or site II or respective mutated sites for miR-132 binding) \pm miR-132 mimic. Reporter assays were performed using a dual luciferase kit. Two-way ANOVA was used to compare the differences among different samples. The results are expressed as mean relative luciferase activities \pm S.E. $(n=4)$. ${ }^{*} P<0.05$.

Published by Bioscientifica Ltd 
A

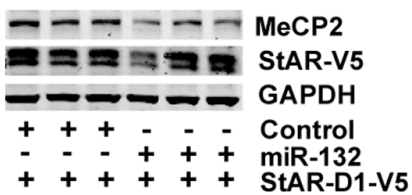

B

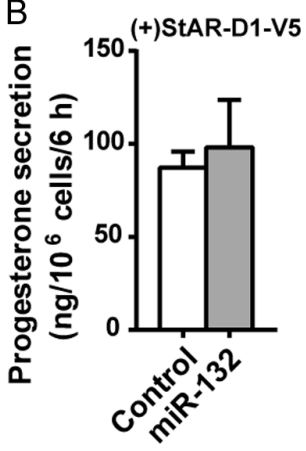

C

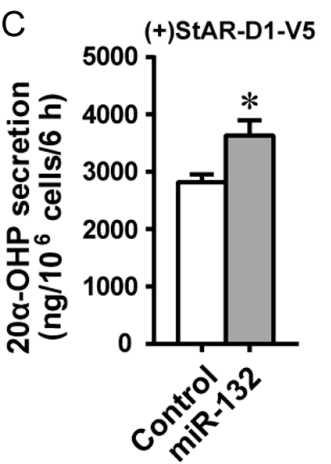

Figure 5

Effects overexpression of StAR and miR-132 in Y1 cells on basal progestin production. $\mathrm{Y} 1$ cells were transiently transfected with $50 \mathrm{nM}$ scrambled oligonucleotide or miR-132 mimic plus mouse StAR-V5 CDNA construct. After $48 \mathrm{~h}$ of transfection, medium was changed to basal medium, dishes incubated for an additional $6 \mathrm{~h}$ and subsequently medium samples collected and analyzed for progesterone and $20 \alpha-\mathrm{OHP}$ by radioimmunoassay. Cell samples were analyzed for overexpressed StAR protein levels by Western blotting. StAR protein levels were normalized to GAPDH. (A) StAR protein expression; (B) secreted progesterone and (C) secreted 20 $\alpha$-OHP. We used one-way ANOVA to compare the differences between control and miR-132 co-transfected samples. Data are presented as means \pm s.E. $(n=4)$. ${ }^{*} P<0.05$.
miR-132 in CHO cells significantly decreased the luciferase activity (Fig. 4B). This inhibition was abolished when binding site I was mutated. However, no inhibitory effect of miR-132 on the activity of the 3' UTR of StAR reporter construct containing site II was detected, indicating that site I is the target of miR-132 action on StAR $3^{\prime}$ UTR (Fig. 4B). The results presented in Fig. 5 demonstrate that overexpression of StAR/StarD1 overcomes the inhibitory action of miR-132 on basal progestin production, and, in fact, increased $20 \alpha$-OHP production.

\section{miR-132 upregulates the expression of 3 $\beta-\mathrm{HSD}$ and $20 \alpha$-HSD activities and progestin production by inhibiting MeCP2 expression}

Next, we investigated the potential mechanism by

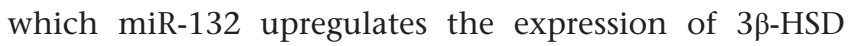
and $20 \alpha$-HSD activities. Since MeCP2, a transcriptional regulatory protein (Hite et al. 2009), was previously shown to be a downstream target of miR-132 in the brain (Wanet et al. 2012) and our current observation that overexpression of miR-132 expression suppressed MeCP2 protein expression in Y1 cells (Fig. 2B), this raised the possibility that this transcription factor plays a regulatory role in miR-132 induction of $3 \beta-H S D$ and $20 \alpha$-HSD enzymes. Initially, we evaluated the separate and combined effects of transfection of Y1 cells with miR-132 and MeCP2 constructs on the mRNA expression of $3 \beta-\mathrm{HSD}$ and $20 \alpha-H S D$. Quantitative RT-PCR data presented in Fig. 6 (A and B) show that overexpression of miR-132 increased mRNA levels of both $3 \beta$-HSD and $20 \alpha-H S D$, but, as before, had no effect on mRNA levels of other genes examined both under basal conditions and in response to cAMP stimulation. In contrast, simultaneous expression of MeCP2 reversed the increased effect on mRNA levels of $20 \alpha-H S D$ in control and cAMP-stimulated cells. Western blotting data presented in Fig. 6C confirmed the miR-132induced suppression of MeCP2 protein expression and the increased expression of MeCP2 protein in cell extracts from cells transfected with the MeCP2 cDNA construct. Likewise, overexpression of miR-132 alone or miR-132 plus MeCP2 decreased progestin production under basal conditions, but increased cAMP-stimulated progesterone secretion (Fig. 6D). The production of $20 \alpha-\mathrm{OHP}$, however, was significantly decreased in cells co-transfected with miR-132 along with MeCP2 as compared to miR-132 alone (Fig. 6E). These studies lead us to conclude that miR-132 induces the expression of two pregnenolone metabolizing enzymes, particularly $20 \alpha-H S D$, through inhibition of $\mathrm{MeCP} 2$ protein expression.

To further examine the contribution of $\mathrm{MeCP} 2$ protein

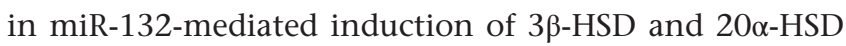
activities, we employed a siRNA strategy to deplete mRNA and protein levels of MeCP2 in Y1 cells. Quantitative RT-PCR results demonstrated that transfection of Y1 cells with MeCP2-specific siRNA reduced MeCP2 mRNA levels by $60-70 \%$ (Fig. 7A). Western blot analysis showed that Y1 cells had approximately $50 \% \mathrm{MeCP} 2$ protein levels when transfected with MeCP2 siRNA (Fig. 7B). In contrast, mRNA levels of $3 \beta$-HSD and $20 \alpha$-HSD were significantly increased (more robustly for $20 \alpha$-HSD) following transfection of Y1 cells with MeCP2 siRNA (Fig. 7A). We also investigated the effect of siRNA-induced depletion of MeCP2 on steroid

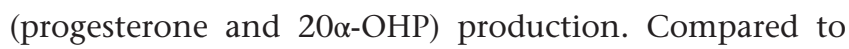
negative control, transfection of $\mathrm{Y} 1$ cells with MeCP2

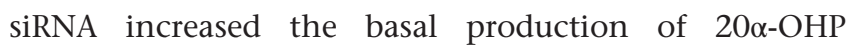
(Fig. 7D). In contrast, no such stimulatory effect was noted on progesterone production (Fig. 7C). These studies 
A

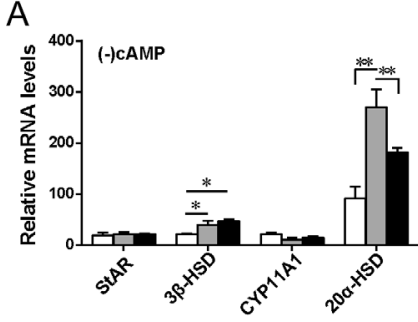

C

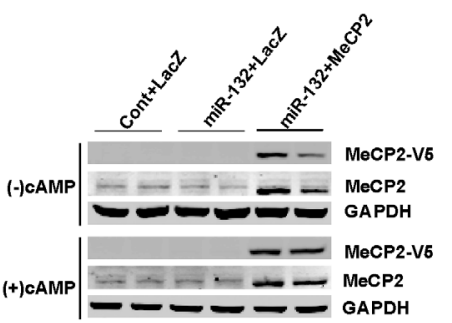

B

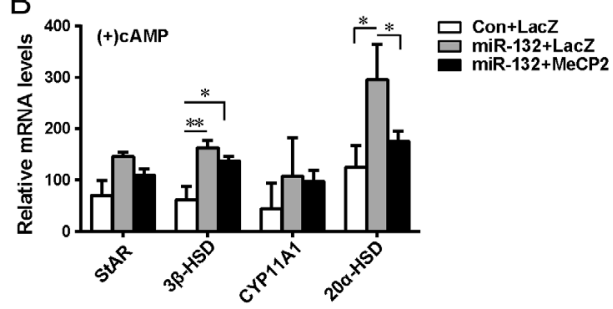

D

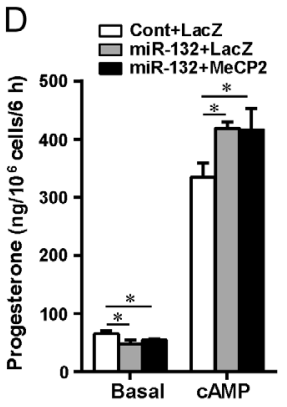

E

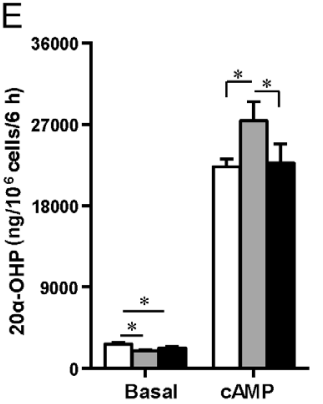

Figure 6

Effects of miR-132 and MeCP2 overexpression on StAR, CYP11A1, 3 $\beta-H S D$ and $20 \alpha-H S D$ expression and progestin production. $Y 1$ cells were transiently transfected with scrambled oligonucleotide or miR-132 mimic \pm mouse MeCP2-V5 cDNA construct or control plasmid pcDNA6-LacZ. Thirty-six to $48 \mathrm{~h}$ after transfection, the cells were incubated in fresh medium for $6 \mathrm{~h}$ without or with CAMP. The mRNA expression of StAR, MeCP2, CYP11A1, 3 -HSD and 20 $\alpha$-HSD in basal (A) or CAMP treated (B) samples was measured by qRT-PCR. (C) Protein levels were analyzed by Western blotting as described under the Experimental Section. The media samples were analyzed for progesterone (D) and 20 $\alpha-\mathrm{OHP}$ (E) content by radioimmunoassay. One-way ANOVA was used to analysis the differences among different samples as showed in the figures. Data are presented as means \pm S.E. $(n=4)$. $* P<0.05 ; * * P<0.01$. led us to conclude that miR-132 upregulates $3 \beta$-HSD and $20 \alpha$-HSD and increases $20 \alpha$-OHP by inhibiting MeCP2 protein expression. These studies also establish that $\mathrm{MeCP} 2$ is a negative regulator of the expression of $20 \alpha$-HSD and also possibly $3 \beta$-HSD.

To further confirm the physiological significance of miR-132 regulation of steroidogenesis, we also carried out loss-of-function and gain-of-function studies using primary rat ovarian granulosa cells. We transfected granulosa cells with miR-132 mimic and anti-miR-132 for $6 \mathrm{~h}$ and subsequently cells were maintained in the basal medium for $24 \mathrm{~h}$. Following addition of Bt $2 \mathrm{cAMP} \pm \mathrm{hHDL} 3$ for $24 \mathrm{~h}$, the medium samples were analyzed for $20 \alpha-\mathrm{OHP}$ content by specific RIAs. As shown in Fig. 8, overexpression of miR-132 increased $20 \alpha-\mathrm{OHP}$ production with and without HDL loading, while knockdown of miR-132 resulted in a significant decrease of $20 \alpha-\mathrm{OHP}$ production from the granulosa cells.

\section{Discussion}

In these studies, we evaluated the role of trophic hormone regulated miR-132 in the regulation of steroidogenesis using a model Y1 adrenal cell line. Although miR-132 together with miR-212 comprises the evolutionary conserved miR-132/212 family, miR-212 expression was almost negligible compared to miR-132 not only in Y1 cells, but also in rat ovarian granulosa cells, mouse Leydig tumor MLTC-1 cells and the rat adrenal gland. Thus, our studies focused on miR-132. The results demonstrated that miR-132 itself is positively regulated
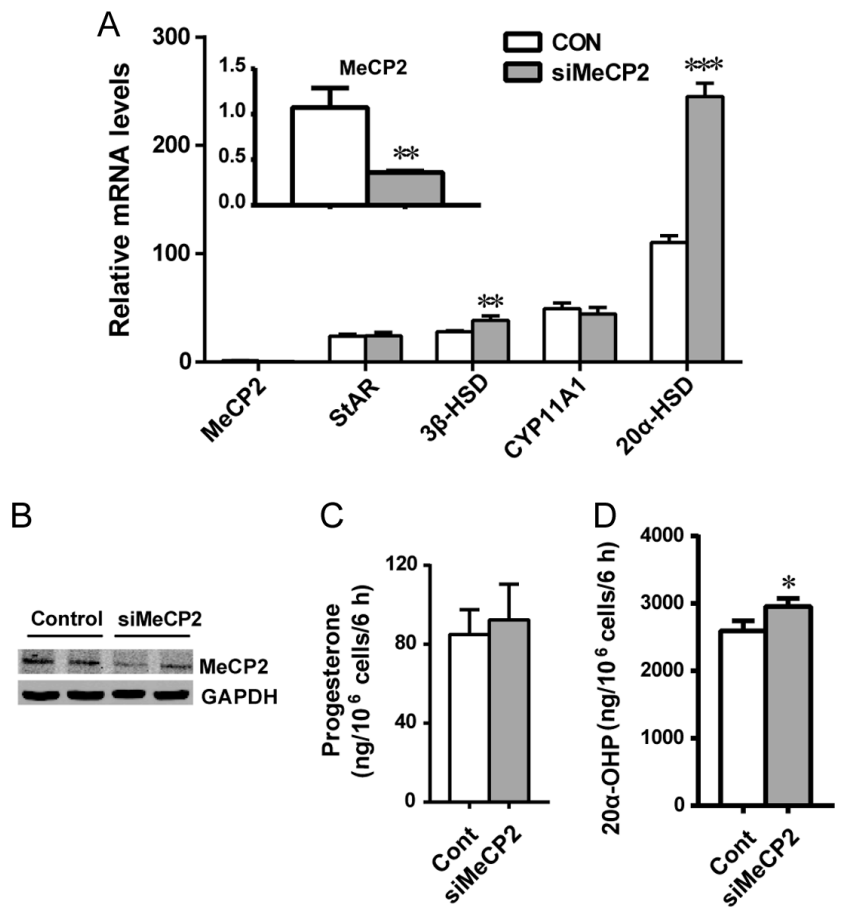

Figure 7

Effects of MeCP2 siRNA on MeCP2, StAR, CYP11A1, 3 -HSD, and 20 $\alpha$-HSD expression and progestin production in $Y 1$ cells. $Y 1$ cells were transiently transfected with mouse MeCP2 siRNA or control (scrambled) siRNA. Thirty-six to $48 \mathrm{~h}$ after transfection, the cells were incubated in fresh medium for $6 \mathrm{~h}$ and, subsequently, the expression of StAR, MeCP2, CYP11A1, 3 $\beta-H S D$ and $20 \alpha-H S D$ was measured by qRT-PCR (A) and/or Western blotting (B) as described under Experimental Section. The media samples were analyzed for progesterone (C) and $20 \alpha-\mathrm{OHP}$ (D) content by radioimmunoassay. We used one-way ANOVA to compare the differences between control and siMeCP2 transfected samples. Data are presented as means \pm S.E. $(n=4) .{ }^{*} P<0.05 ;{ }^{*} P<0.01, * * * P<0.001$. http://jme.endocrinology-journals.org DOI: 10.1530/JME-17-0011
○ 2017 Society for Endocrinology Printed in Great Britain 

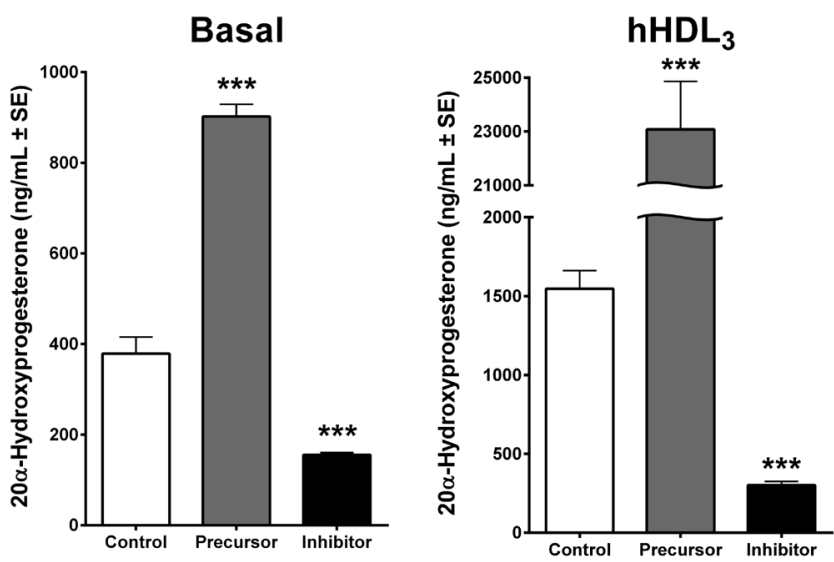

Figure 8

Effect of treatment of rat ovarian granulosa cells with mimic or anti-miR-132 on $20 \alpha$ - OHP production. Primary rat granulosa cells were transfected with \pm miR-132 mimic, anti-miR-132 or scrambled oligonucleotide using PolyjetTM for $6 \mathrm{~h}$, and cells were maintained in basal medium for $24 \mathrm{~h}$ before treatment with Bt2cAMP $(2.5 \mathrm{mM}) \pm \mathrm{HDL}$ $(500 \mu \mathrm{g} / \mathrm{mL})$ for an additional $24 \mathrm{~h}$. At the end of incubation, medium samples were analyzed for $20 \alpha-\mathrm{OHP}$ content by radioimmunoassay. We used one-way ANOVA to compare the differences between control and treated samples. Data are presented as means \pm s.E. $(n=4) . * P<0.05$; $* * P<0.01, * * * P<0.001$

by cAMP, the second messenger of trophic hormone, in Y1, granulosa and MLTC-1 cells and also by ACTH in the rat adrenal gland in vivo. Studies revealed that miR-132 inhibits steroidogenesis by a dual mechanism. Under basal conditions, miR-132 attenuates steroidogenesis by reducing StAR protein levels. In response to hormonal stimulation, miR-132 induces the expression of 3 3 -HSD and $20 \alpha$-HSD through inhibition of transcription factor MeCP2. This, in turn, causes sequential conversion of the CYP11A1 reaction product pregnenolone to progesterone and then biologically inactive $20 \alpha-O H P$ (Fig. 9). Together, these data indicate that miR-132 plays a key role in the posttranscriptional regulation of steroid hormone biosynthesis.

miR-132 expression is transcriptionally induced by cAMP-responsive element-binding (CREB) protein (Impey et al. 2004, Vo et al. 2005, Wanet et al. 2012) and inhibited by repressor element 1 silencing transcription factor/ neuron-restrictive silencer factor (REST/NRSF) (Conaco et al. 2006, Wanet et al. 2012). miR-132 has been most extensively studied in the brain, where it is implicated in neuronal differentiation and function (Impey et al. 2004, Vo et al. 2005, Wu \& Xie 2006, Conaco et al. 2006, Cheng et al. 2007, Wayman et al. 2008). Increasing evidence now suggests that miR-132 also regulates multiple processes in non-neuronal tissues. For example, miR-132 expression is induced by lipopolysaccharide (LPS)

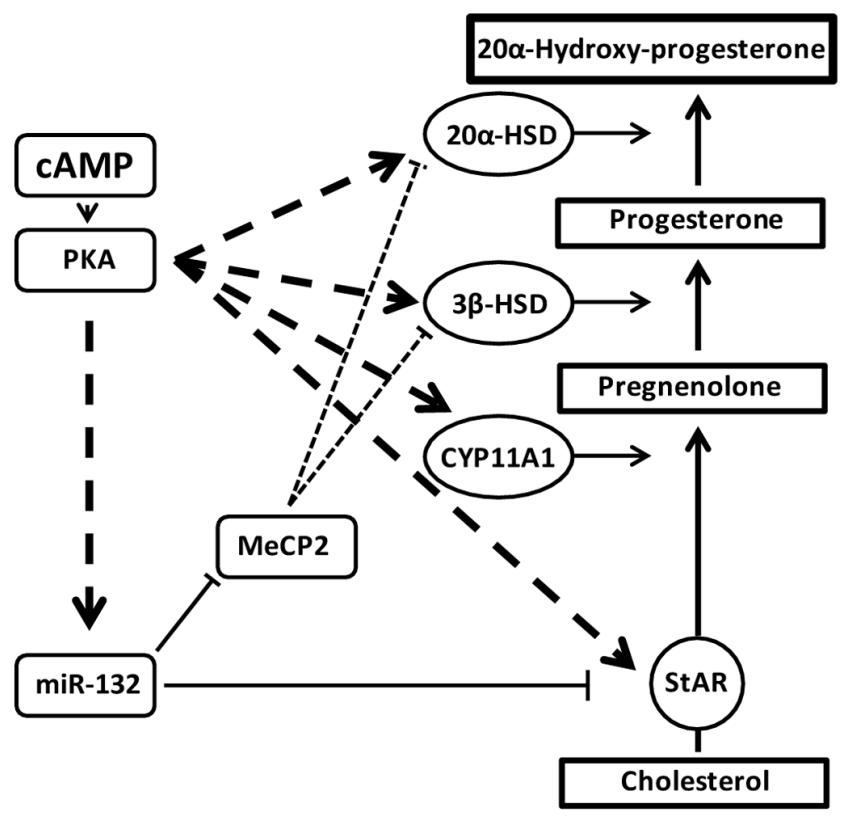

Figure 9

Sites of action of miR-132 on the steroidogenic pathway. Based on the data obtained we propose that miR-132 regulates steroidogenesis by: (1) inhibiting StAR protein expression and StAR-mediated cholesterol transport to mitochondria and (2) suppressing MeCP2 expression to cause primarily increased expression of $20 \alpha-H S D$ and consequently $20 \alpha-H S D$ catalyzed increased conversion of progesterone into an inactive metabolite, $20 \alpha-\mathrm{OHP}$. Also, we believe that the first pathway is more physiologically relevant.

in THP-1 cells (Taganov et al. 2006) and is overexpressed in chronic lymphoblastic leukemia (Calin et al. 2004). More recent studies suggest that miR-132 regulates innate immunity (Lagos et al. 2010), regulates nutritional stressinduced chemokine production (Strum et al. 2009) and it (along with family member miR-212) contributes to the pathogenesis of cardiac hypertrophy and cardiomyocyte autophagy (Ucar et al. 2012). We found that the expression of miR-132 was upregulated in Y1 adrenal cells, ovarian granulosa cells and testicular Leydig tumor MLTC-1 cells in response to second messenger, cAMP, although the extent of cAMP stimulation of miR-132 expression varied considerably among cell types, as well as in adrenals of rats treated in vivo with ACTH. cAMP-mediated modulation of miR-132 expression has also been reported in nonsteroidogenic cells; the cAMP analog 8-Br-cAMP-induced miR-132 expression in primary lymphatic endothelial cells (LECs), whereas the cAMP antagonist RpAMPs partially blocked the induction of Kaposi's sarcoma-associated herpes virus (KSHV)-infected LECs (Lagos et al. 2010).

Although miR-132 and miR-212 comprise the evolutionary conserved miR-132/212 cluster (Wanet et al. 2012, Remenyi et al. 2013), and these microRNAs share

Published by Bioscientifica Ltd. 
the same transcript and the same $5^{\prime}$ seed sequence in humans and rodents, qRT-PCR measurements indicated that miR-212 was expressed several hundredfold lower than miR-132 both under basal conditions and in response to cAMP stimulation. The data are consistent with other reports where only miR-132 was found to be induced and functional in various biological systems (Calin et al. 2004, Taganov et al. 2006, Cheng et al. 2007, Klein et al. 2007). However, a previous report provided evidence that both miR-132 and miR-212 were highly upregulated in ovulatory mouse mural granulosa cells in vivo in response to hCG treatment and under an in vitro culture condition following cAMP stimulation (Fiedler et al. 2008). At present, we are unable to provide an exact explanation for the differences between our results using rat granulosa cells with this report (Fiedler et al. 2008) that employed mouse mural granulosa cells. It may be related to species differences, granulosa cell types or both.

Our studies demonstrate that miR-132 negatively regulates steroidogenesis in Y1 cells by a novel dual mechanism. miR-132 can directly repress StAR protein expression through its binding to site I (GACTGTT), but not site II, in the 3' UTR of the mouse StAR gene, thereby negatively regulating StAR-mediated cholesterol transport to mitochondria for cholesterol side-chain cleavage catalyzed by CYP11A1 for pregnenolone production and, consequently, progestin (steroid) production. We further demonstrated that overexpression of miR-132 reduced the protein levels of StAR protein without impacting its mRNA levels both under basal conditions and in response to cAMP stimulation. These results, thus, validate StAR as a direct target of miR-132. The observed reduction in StAR protein levels is possibly due to miR-132 interference with the translation process. At a functional level, the inhibition of basal levels of StAR protein is reflected by corresponding decreases in the basal production of progesterone and $20 \alpha-\mathrm{OHP}$ in Y1 cells transfected with miR-132.

Our studies also indicate that treatment of cells overexpressing miR-132 with cAMP increased the secretion of stimulated progesterone and $20 \alpha-\mathrm{OHP}$ secretion, as a result of increased expression of $3 \beta-\mathrm{HSD}$ and $20 \alpha-H S D$, and cAMP-stimulated StAR protein expression. Although in the current studies we have identified StAR protein as a downstream target of miR-132, it appears that cAMP-stimulated cells, despite significantinhibition incAMP-inducedStAR protein levels by miR-132, still maintain more than an adequate amount of this protein to maximally stimulate steroidogenesis.
This, coupled with increased expression of $3 \beta-H S D$ and $20 \alpha-H S D$, assures a rapid $3 \beta$-HSD-catalyzed conversion of CYP11A1 reaction product pregnenolone to biologically active progesterone and, subsequently, quantitative conversion of progesterone to inactive $20 \alpha-\mathrm{OHP}$, as a result of the miR-132-mediated robust induction of $20 \alpha$-HSD. Additional studies confirmed these changes by demonstrating that transfection of $Y 1$ cells with miR-132 increased the conversion of $\left[{ }^{3} \mathrm{H}\right]$ pregnenolone into $\left[{ }^{3} \mathrm{H}\right]$ $20 \alpha-\mathrm{OHP}$ and preferentially enhanced the production

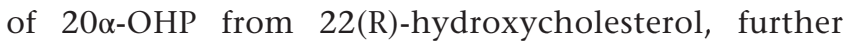
confirming that miR-132 promotes the production of $20 \alpha$-OHP by upregulating the functional expression of $3 \beta$-HSD and 20 $\alpha$-HSD enzymes. Because cultured Y1 cells, both under basal conditions and in response to trophic hormone stimulation, primarily synthesize and secrete $20 \alpha$-hydroxy- $\Delta 4$-pregnene-3-one (20 $\alpha$-OHP) and $11 \beta, 20 \alpha$-dihydroxy- $\Delta 4$-pregnene-3-one (11 $\beta, 20 \alpha$-OHP), along with small amounts of progesterone (Rainey et al. 2004), it was important to document that overexpression or knockdown of miR-132 altered $20 \alpha-\mathrm{OHP}$ production in cells that primarily secrete progesterone as their steroid product. Indeed, overexpression or knockdown of miR132 in primary rat ovarian granulosa cells increased

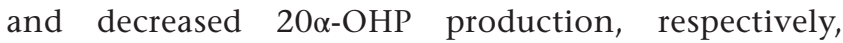
thus confirming that the observed effects on steroid production were not due to unique characteristics of Y1 cells.

In addition, we observed that overexpressed miR-132 inhibited MeCP2 protein expression, a well-established downstream target of miR-132 (Klein et al. 2007), which raised the possibility that MeCP2 might be involved in miR-132-mediated induction of $3 \beta-\mathrm{HSD}$ and $20 \alpha-\mathrm{HSD}$. This possibility was confirmed with the use of MeCP2specific siRNA. Transfection of Y1 cells with MeCP2specific siRNA reduced MeCP2 mRNA levels by $60-70 \%$ and protein levels by $\sim 50 \%$. Under these experimental conditions, the mRNA levels of $3 \beta-\mathrm{HSD}$ and $20 \alpha-\mathrm{HSD}$ were significantly increased (more robustly for $20 \alpha-H S D$ ). Likewise, transfection of $\mathrm{Y} 1$ cells with MeCP2 siRNA increased the basal production of $20 \alpha-O H P$. These studies led us to conclude that miR-132 upregulates 3 $\beta$-HSD and $20 \alpha-H S D$ mRNA expression and increases $20 \alpha-\mathrm{OHP}$ potentially by inhibiting MeCP2 protein expression. Furthermore, direct experimental evidence is needed to demonstrate whether MeCP2 directly inhibits 3 3 -HSD and/or 20 $\alpha$-HSD activity. These studies also establish that $\mathrm{MeCP} 2$ is a negative regulator of the expression of $3 \beta-\mathrm{HSD}$ and $20 \alpha$-HSD enzymes. http://jme.endocrinology-journals.org DOI: 10.1530/JME-17-0011
() 2017 Society for Endocrinology Printed in Great Britain
Published by Bioscientifica Ltd 
In summary, these studies demonstrate for the first time that a trophic hormone-regulated microRNA, miR-132, regulates steroidogenesis by a novel dual mechanism. It attenuates steroidogenesis by repressing StAR protein expression and by causing the induction of $20 \alpha-H S D$ via inhibition of MeCP2, which results in the generation of biologically inactive steroid. Our studies suggest that miR-132 interferes with steroidogenesis not only by upregulating $20 \alpha-H S D$, but also by limiting the availability of cholesterol precursor for side-chain cleavage via inhibition of StAR. Further studies are required to determine how tissue-specific trophic hormones, which positively regulate almost all processes linked to steroidogenesis, also control the events that are connected with the inhibition of the steroidogenic process. In addition, further studies will be needed to further explore the roles of miR-132 and minor miR-212 in trophic hormone regulation of adrenal and ovarian steroidogenesis and expression, steroid profiles and expression of $3 \beta$-HSD and $20 \alpha-H S D$ in vivo. Finally, the data suggest that under conditions of markedly elevated ACTH, the increased miR-132, and to a very lesser degree miR-211, expression tends to restrain the maximum glucocorticoid output by the adrenals, thus potentially leading to a suboptimal glucocorticoid response in some clinical settings.

\section{Declaration of interest}

The authors declare that there is no conflict of interest that could be perceived as prejudicing the impartiality of the research reported.

\section{Funding}

This work was supported, in whole or in part, by National Institutes of Health, NHLBI, Grant, 2R01HL33881. This work was also supported by the Office of Research and Development, Medical Service, Department of Veterans Affairs.

\section{Author contribution statement}

$\mathrm{S} \mathrm{A}, \mathrm{Z} \mathrm{H}, \mathrm{F} \mathrm{K}$ and W J S conceived and designed the experiments. Z H and W J S performed the experiments. Z H and W J S analyzed the data. Z H, S A, F $\mathrm{K}$ and $\mathrm{W} J \mathrm{~S}$ wrote the paper. $\mathrm{Z} \mathrm{H}, \mathrm{W} J \mathrm{~S}, \mathrm{~F} \mathrm{~K}$ and $\mathrm{S} A$ edited the manuscript.

\section{References}

Ambros V 2004 The functions of animal microRNAs. Nature $\mathbf{4 3 1}$ 350-355. (doi:10.1038/nature02871)

Arakane F, King S, Du Y, Kallen C, Walsh L, Watari H, Stocco D \& Strauss J 1997 Phosphorylation of steroidogenic acute regulatory protein (StAR) modulates its steroidogenic activity. Journal of Biological Chemistry 272 32656-32662. (doi:10.1074/ jbc.272.51.32656)
Azhar S, Nomoto A, Leers-Sucheta S \& Reaven E 1998 Simultaneous induction of an HDL receptor protein (SR-BI) and the selective uptake of HDL-cholesteryl esters in a physiologically relevant steroiodgenic cell model. Journal of Lipid Research 39 1616-1628.

Azhar S, Nomoto A \& Reaven E 2002 Hormonal regulation of adrenal microvillar channel formation. Journal of Lipid Research 43 861-871.

Bartel DP 2009 MicroRNAs: target recognition and regulatory functions. Cell 136 215-233. (doi:10.1016/j.cell.2009.01.002)

Bushati N \& Cohen SM 2007 microRNA functions. Annual Review of Cell and Developmental Biology 23 175-205. (doi:10.1146/annurev. cellbio.23.090506.123406)

Calin GA, Liu CG, Sevignani C, Ferracin M, Damitru CD, Shimizu M, Cimmino A, Zupo S, Dono M, Dell'Aquila ML, et al. 2004 MicroRNA profiling reveals distinct signatures in B cell chronic lymphocytic leukemias. PNAS 101 11755-11760. (doi:10.1073/pnas.0404432101)

Cheng HY, Papp JW, Varlamova O, Dziema H, Russell B, Curfman JP, Nakazawa T, Shimizu K, Okamura H, Imey S, et al. 2007 MicroRNA modulation of circadian-clock period and entrainment. Neuron $\mathbf{5 4}$ 813-829. (doi:10.1016/j.neuron.2007.05.017)

Christenson L \& Strauss III J 2000 Steroidogenic acute regulatory protein (StAR) and the intramitochondrial translocation of cholesterol. Biochimica et Biophysica Acta 1529 175-187. (doi:10.1016/S13881981(00)00147-5)

Conaco C, Otto S, Han J-J \& Mandel G 2006 Reciprocal actions of REST and a microRNA promote neuronal identity. PNAS 103 2422-2427. (doi:10.1073/pnas.0511041103)

Epstein LF \& Orme-Johnson NR 1991 Regulation of steroid hormone biosynthesis. Identification of precursors of a phosphoprotein targeted to the mitochondrion in stimulated rat adrenal cortex cells. Journal of Biological Chemistry 266 19739-19745.

Fabian MR, Sonenberg N \& Filipowicz W 2010 Regulation of mRNA translation and stability by microRNAs. Annual Review of Biochemistry 79 351-379. (doi:10.1146/annurev-biochem-060308-103103)

Fiedler SD, Carletti MZ, Hong X \& Christenson LK 2008 Hormonal regulation of MicroRNA expression in periovulatory mouse mural granulosa cells. Biology of Reproduction 79 1030-1037. (doi:10.1095/ biolreprod.108.069690)

Graham J \& Clarke C 1997 Physiological action of progesterone in target tissues. Endocrine Reviews 18 502-519. (doi:10.1210/edrv.18.4.0308)

Greenberg AS, Shen WJ, Muliro K, Patel S, Souza SC, Roth RA \& Kraemer FB 2001 Stimulation of lipolysis and hormone-sensitive lipase via the extracellular signal-regulated kinase pathway. Journal of Biological Chemistry 276 45456-45461. (doi:10.1074/jbc.M104436200)

Hiort O, Holterhus P \& Nitsche E 1998 Physiology and pathophysiology of androgen action. Baillière's Clinical Endocrinology and Metabolism 12 115-132. (doi:10.1016/S0950-351X(98)80495-3)

Hite K, Adams V \& Hansen J 2009 Recent advances in MeCP2 structure and function. Biochemistry and Cell Biology 87 219-227. (doi:10.1139/ O08-115)

Hu J, Zhang Z, Shen W \& Azhar S 2010 Cellular cholesterol delivery, intracellular processing and utilization for biosynthesis of steroid hormones. Nutrition and Metabolism 7 47. (doi:10.1186/17437075-7-47)

Hu Z, Shen W, Kraemer F \& Azhar S 2012 MicroRNAs 125a and 455 repress lipoprotein-supported steroidogenesis by targeting scavenger receptor class B type I in steroidogenic cells. Molecular and Cellular Biology 32 5035-5045. (doi:10.1128/MCB.01002-12)

$\mathrm{Hu}$ Z, Hu J, Zhang Z, Shen W, Yun C, Berlot C, Kraemer F \& Salman A $2013 a$ Regulation of expression and function of scavenger receptor class $\mathrm{B}$, type I (SR-BI) by $\mathrm{Na}+\mathrm{H}+$ exchanger regulatory factors (NHERFs). Journal of Biological Chemistry 288 11416-11435. (doi:10.1074/jbc.M112.437368)

Hu Z, Shen WJ, Cortez Y, Tang X, Liu LF, Kraemer FB \& Azhar S 2013b Hormonal regulation of microRNA expression in steroid producing cells of the ovary, testis and adrenal gland. PLOS ONE 8 e78040. (doi:10.1371/journal.pone.0078040) 
Hu Z, Hu J, Shen W, Kraemer F \& Azhar S 2015 A novel role of saltinducible kinase 1 (SIK1) in the post-translational regulation of scavenger receptor class B type 1 activity. Biochemistry 54 6917-6930. (doi:10.1021/acs.biochem.5b00147)

Impey S, McCorkle S, Cha-Molstad H, Dwyer J, Yochum G, Boss J, McWeeney S, Dunn JJ, Mandel G \& Goodman R 2004 Defining the CREB regulon: a genome-wide analysis of transcription factor regulatory regions. Cell 119 1041-1054. (doi:10.1016/S00928674(04)01159-6)

Jefcoate C, McNamara B, Artmenko I \& Yamazaki T 1992 Regulation of cholesterol movement to mitochondrial P450scc in steroid hormone synthesis. Journal of Steroid Biochemistry and Molecular Biology $\mathbf{4 3}$ 751-767. (doi:10.1016/0960-0760(92)90305-3)

Jones P \& Hsueh A 1982 Regulation of ovarian 3 $\beta$-hydroxysteroid dehydrogenase activity by gonadotropin-releasing hormone and follicle-stimulating hormone in cultured rat granulosa cells. Endocrinology 110 1663-1671. (doi:10.1210/endo-110-5-1663)

Jones-Rhoades MW, Bartel DP \& Bartel B 2006 MicroRNAS and their regulatory roles in plants. Annual Review of Plant Biology 57 19-53. (doi:10.1146/annurev.arplant.57.032905.105218)

Katzenellenbogen B, Choi I, Delage-Mourroux R, Ediger T, Martini P, Montano M, Sun J, Weis K \& Katzenellenbogen J 2002 Molecular mechanisms of estrogen action: selective ligands and receptor pharmacology. Journal of Steroid Biochemistry and Molecular Biology 74 279-285. (doi:10.1016/S0960-0760(00)00104-7)

Kitahara Y, Nakamura K, Kogure K \& Minegishi T 2013 Role of microRNA-136-3p on the expression of luteinizing hormone-human chorionic gonadotropin receptor mRNA in rat ovaries1. Biology of Reproduction 89 1525-1525. (doi:10.1095/biolreprod.113.109207)

Klein ME, Lioy DE, Lin M, Impey S, Mandel G \& Goodman RH 2007 Homeostatic regulation of MeCP2 expression by a CREB-induced microRNA. Nature Neuroscience 10 1513-1514. (doi:10.1038/nn2010)

Kraemer F \& Shen W 2002 Hormone-sensitive lipase: control of intracellular tri-(di)acylglycerol and cholesteryl ester hydrolysis. Journal of Lipid Research 43 1585-1594. (doi:10.1194/jlr.R200009-JLR200)

Lagos D, Pollara G, Henderson S, Gratrix F, Fabini M, Milne RSB, Gotch F \& Boshoff C 2010 miR-132 regulates antiviral innate immunity through suppression of the p300 transcriptional co-activator. Nature Cell Biology 12 513-519. (doi:10.1038/ncb2054)

LaVoie H \& King S 2009 Transcriptional regulation of steroidogenic genes: STARD1, CYP11A1 and HSD3B. Experimental Biology and Medicine 234 880-907. (doi:10.3181/0903-MR-97)

Lehoux JG, Fleury A, Ducharme L \& Hales DB 2004 Phosphorylation of the hamster adrenal steroidogenic acute regulatory protein as analyzed by two-dimensional polyacrylamide gel electrophoreses. Molecular and Cellular Endocrinology 215 127-134. (doi:10.1016/j. mce.2003.11.002)

Manna P, Chandrala S, King S, Jo Y, Counis R, Hutaniemi I \& Stocco DM 2006 Molecular mechanisms of insulin-like growth factor-mediated regulation of the steroidogenic acute regulatory protein in mouse Leydig cells. Molecular Endocrinology 20 362-378. (doi:10.1210/ me.2004-0526)

Manna PR, Dyson MT \& Stocco DM 2009 Regulation of the steroidogenic acute regulatory protein gene expression: present and future perspectives. Molecular Human Reproduction 15 321-333. (doi:10.1093/molehr/gap025)

Mao J, Duan RW, Zhong L, Gibori G \& Azhar S 1997 Expression, purification and characterization of the rat luteal 20 alphahydroxysteroid dehydrogenase. Endocrinology 138 182-190. (doi:10.1210/endo.138.1.4825)

Menon B, Sinden J, Franzoromain M, Botta RB \& Menon KM 2013 Regulation of LH receptor mRNA binding protein by miR-122 in rat ovaries. Endocrinology 154 4826-4834. (doi:10.1210/en.2013-1619)

Miller W 2008 Steroidogenic enzymes. Endocrine Development 13 1-18. (doi:10.1159/000134751)
Miller WL \& Bose HS 2011 Early steps in steroidogenesis: intracellular cholesterol trafficking thematic review series: genetics of human lipid diseases. Journal of Lipid Research 52 2111-2135. (doi:10.1194/ jlr.R016675)

Morohaku K, Pelton SH, Daugherty DJ, Butler WR, Deng W \& Selvaraj V 2014 Translocator protein/peripheral benzodiazepine receptor is not required for steroid hormone biosynthesis. Endocrinology 155 89-97. (doi:10.1210/en.2013-1556)

Nair AK, Kash JC, Peegel H \& Menon KM 2002 Post-transcriptional regulation of luteinizing hormone receptor mRNA in the ovary by a novel mRNA-binding protein. Journal of Biological Chemistry 277 21468-21473. (doi:10.1074/jbc.M111653200)

Newton R 2000 Molecular mechanisms of glucocorticoid action: what is important? Thorax 55 603-613. (doi:10.1136/thorax.55.7.603)

Papadopoulos V \& Miller W 2012 Role of mitochondria in steroidogenesis. Best Practice and Research 26 771-790. (doi:10.1016/j. beem.2012.05.002)

Parker KL, Chaplin DD, Wong M, Seidman JG, Smith JA \& Schimmer BP 1985 Expression of murine 21-hydroxylase in mouse adrenal glands and in transfected Y1 adrenocortical tumor cells. PNAS 82 7860-7864. (doi:10.1073/pnas.82.23.7860)

Payne A \& Youngblood G 1995 Regulation of expression of steroidogenic enzymes in Leydig cells. Biology of Reproduction $\mathbf{5 2}$ 217-225. (doi:10.1095/biolreprod52.2.217)

Payne A \& Hales D 2004 Overview of steroidogenic enzymes in the pathway from cholesterol to active steroid hormones. Endocrine Reviews 25 947-970. (doi:10.1210/er.2003-0030)

Pearce D, Bhargava A \& Cole T 2003 Aldosterone: its receptor, target genes, and actions. Vitamins as Hormones 66 29-76. (doi:10.1016/ s0083-6729(03)01002-1)

Rainey WE, Saner K \& Schimmer BP 2004 Adrenocortical cell lines. Molecular and Cellular Endocrinology 228 23-38. (doi:10.1016/j. mce.2003.12.020)

Reaven E, Zhan L, Nomoto A, Leers-Sucheta S \& Azhar S 2000 Expression and microvillar localization of scavenger receptor class $\mathrm{B}$, type I (SR-BI) and selective cholesteryl ester uptake in Leydig cells from rat testis. Journal of Lipid Research 41 343-356.

Remenyi J, Bosch MWMVD, Palygin O, Mistry RB, Mckenzie C, Macdonald A, Hutvagner G, Arthur JSC, Frenguelli BG \& Pankratov Y 2013 miR-132/212 knockout mice reveal roles for these miRNAs in regulating cortical synaptic transmission and plasticity. PLOS ONE 8 65-65. (doi:10.1371/journal.pone.0062509)

Sewer M, Dammer E \& Jagarlapudi S 2007 Transcriptional regulation of adrenocortical steroidogenic gene expression. Drug Metabolism Reviews 39 371-388. (doi:10.1080/03602530701498828)

Simpson E, Lauber M, Demeyer M, Means G, Mahendro M, Kilgore M, Mendelson C \& Waterman M 1992 Regulation of expression of the genes encoding steroidogenic enzymes in the ovary. Journal of Steroid Biochemistry and Molecular Biology 41 409-413. (doi:10.1016/09600760(92)90366-Q)

Skalsky RL \& Cullen BR 2010 Viruses, microRNAs, and host interactions. Annual Review of Microbiology 64 123-141. (doi:10.1146/annurev. micro.112408.134243)

Stocco D 2000 Intramitochondrial cholesterol transfer. Biochimica et Biophysica Acta 1486 184-197. (doi:10.1016/S1388-1981(00)00056-1)

Stocco D \& Clark B 1996 Regulation of the acute production of steroids in steroidogenic cells. Endocrine Reviews 17 221-244. (doi:10.1210/ edrv-17-3-221)

Strålfors P, Björgell P \& Belfrage P 1984 Hormonal regulation of hormone-sensitive lipase in intact adipocytes: identification of phosphorylated sites and effects on the phosphorylation by lipolytic hormones and insulin. PNAS 81 3317-3321. (doi:10.1073/ pnas.81.11.3317)

Strum JC, Johnson JH, Ward J, Xie H, Field J, Hester A, Alford A \& Waters KM 2009 MicroRNA regulates nutritional stress-induced http://jme.endocrinology-journals.org

DOI: 10.1530/JME-17-0011
() 2017 Society for Endocrinology Printed in Great Britain
Published by Bioscientifica Ltd 
chemokine production through repression of Sirt1. Molecular Endocrinology 23 1876-1884. (doi:10.1210/me.2009-0117)

Taganov KD, Boldin MP, Chang K-J \& Baltimore D 2006 NF-kappaBdependent induction of microRNA miR-146, an inhibitor targeted to signaling proteins of innate immune responses. PNAS 103 12481-12486. (doi:10.1073/pnas.0605298103)

Ucar A, Gupta SK, Fiedler J, Erikci E, Kardasinski M, Batkai S, Dangwal S, Kumarswamy R, Bang C, Holzmann A, et al. 2012 The miRNA212/132 family regulates both cardiac hypertrophy and cardiomyocyte autophagy. Nature Communications 31078. (doi:10.1038/ncomms2090)

Vo N, Klein M, Varlamova O, Keller D, Yamamoto T, Goodman R \& Impey S 2005 A cAMP-response element binding protein-induced microRNA regulates neuronal morphogenesis. PNAS $\mathbf{1 0 2}$ 16426-16431. (doi:10.1073/pnas.0508448102)

Wanet A, Tacheny A, Arnould T \& Renard P 2012 miR-212/132 expression and functions: within and beyond the neuronal compartment. Nucleic Acids Research 40 4742-4753. (doi:10.1093/ nar/gks151)
Wang H, Hu L, Dalen K, Dorward H, Marcinkiewicz A, Russell D, Gong D, Londos C, Yamaguchi T \& Holm C 2009 Activation of hormonesensitive lipase requires two steps, protein phosphorylation and binding to the PAT-1 domain of lipid droplet coat proteins. Journal of Biological Chemistry 284 32116-32125. (doi:10.1074/jbc. M109.006726)

Wayman G, Davare M, Ando H, Fortin D, Varlamova O, Cheng H-YM, Marks D, Obrietan K, Soderling T, Goodman R, et al. 2008 An activity-regulated microRNA controls dendritic plasticity by downregulating p250GAP. PNAS 105 9093-9098. (doi:10.1073/ pnas.0803072105)

Wu J \& Xie X 2006 Comparative sequence analysis reveals an intricate network among REST, CREB and miRNA in mediating neuronal gene expression. Genome Biology 7 R85. (doi:10.1186/gb-2006-79-r85)

Yao N, Yang BQ, Liu Y, Tan XY, Lu CL, Yuan XH \& Ma X 2010 Folliclestimulating hormone regulation of microRNA expression on progesterone production in cultured rat granulosa cells. Endocrine $\mathbf{3 8}$ 158-166. (doi:10.1007/s12020-010-9345-1)

Received in final form 6 July 2017

Accepted 20 July 2017

Accepted preprint published online 20 July 2017 